American Research Journal of English and Literature

ISSN (Online)-2378-9026

Volume 3, Issue 1, 1-6 Pages

DOI:10.21694/2378-9026.17003

\title{
Proposing a Pitch-meter for English Tone-reading
}

\author{
Acheoah, John Emike (PhD) \\ Department of European Languages, Faculty of Arts, Social and Management Sciences \\ Federal University, Birnin-kebbi, Nigeria \\ actualemike@gmail.com
}

Received Date: April 14, 2017

Accepted Date: April 27, 2017

Published Date: May 10, 2017

\begin{abstract}
This study is very significant because it presents a new model for reading English words and stretches. The English phonemes are segmental (vowel and consonant sounds) and suprasegmental (stress, intonation, rhythm). The analysis of tone in English and any other language cannot be clear without knowledge of segmental phonemes which produce tone in a stretch of utterance. The literature of phonetics and phonology shows that there are different frameworks for reading tone in English. In this study, I simply advance knowledge in the literature by evolving a notational structure for tone-reading (the "Notational Model"). Tone and intonation are potent in connected speech (sentences of conversational exchanges). The rising and falling of voice-pitch during speech is known as intonation. English intonation types include: falling intonation (tune I which moves from a high pitch to a low pitch), rising intonation (tune II which moves from a low pitch to a high one) and combined intonation.
\end{abstract}

Keywords: Pitch-meter, tone-reading, Notational Model, stress, intonation, rhythm

\section{INTRODUCTION}

A study that evolves pitch-meter for reading English is worthy of scholarly attention particularly because there no longer exists a monolithic form of English (Awonusi 2004:204); native speakers of English cannot determine how the language can be used in non-native regions even at the level of phonology. In this paper, the researcher proposes the "Notational Model" which is essentially pitch-meter for reading English words both in isolation and in connected speech1. Ladfoged (1975) submits: "Vowels and consonants can be thought of as the segments of which speech is composed." The English vowel is articulated without any obstruction of airstream as in the production of English consonants. They are classified into monophthongs (pure vowels), diphthongs and triphthongs (sequences of vowel sounds produced when the articulators glide from the point at which the articulation begins to the point at which the sound is fully produced). There are twelve pure vowels in English RP Received Pronunciation. Roach (2000) shows the English vowel charts. The production of English consonant phonemes presupposes obstruction of airstream due to partial or complete friction. There are lenis (voiced consonants) and fortis (voiceless consonants) in English RP. See Roach et al (2006) for more insights on English segmental phonemes.

\section{TONE IN SBE (STANDARD BRITISH ENGLISH)}

Akinjobi (2000) views intonation as a major feature of many languages. He asserts that in "tonal" languages such as Nigerian languages, variation in pitch is used to contrast the meaning of individual words while in "intonational" languages such as English it is the feature of the word group. Tone and intonation are inseparable. The various intonation types in the literature are present in tone languages, and this is because tones are not 
absolute but relative pitches; for a tone to be heard as a high one, it must be in a high-pitch environment in a linguistic stretch. Stress and intonation are instrumental to the discussion of English tone. Acheoah (2013) submits: "Stress is the degree of prominence with which a syllable is uttered. It is a prosodic feature on a syllable of a word." For elaborate discussion of English prosodic features see Czaykowska-Hogins and Dibrovolsky (2000), Gimson (1970) and Jowitt (1991). There are three main stress types in Standard British English: primary, secondary and weak or tertiary stresses. Some rules of stress-placement in SBE are as follows:

1. A monosyllabic word is stressed when it is said in isolation;

2. In two-syllable words, one syllable is stressed and the other is not (there are two-syllable words in English which have primary stress on both syllables e.g. 'mis'manage, 'deep-'rooted, 'cri'sis,' Ju'ly );

3. In polysyllabic words, one of the syllables is stressed and the others are not stressed;

4. Nouns, adjectives, adverbs and negatives are normally stressed;

5. Articles, pronouns, prepositions and auxiliary verbs are not stressed except for emphasis;

6. In polysyllabic words, salient syllables do not usually follow each other in succession.

The discussion of tone in English presupposes understanding the term "rhythm" which is a regular succession of weak and strong stresses, accents and sounds. Without rhythm, speech is monotonous, uncommunicative and unappealing. There are two basic types of rhythm in English: formal and informal rhythm; see Acheoah (ibid.) for more tips on English rhythm.

\section{Pitch-Meter For English TONE-REAding: A Proposal}

I use arbitrary notations to represent English tone reading: Don (falling tune); Din (rising tune); Do ${ }^{\text {Deg. } x}$ (falling tune degree $\mathrm{x}$ where " $\mathrm{x}$ is any pitch contour measured in Hindu Arabic Numeral) Din ${ }^{\text {Deg. } x}$ (rising tune degree $\mathrm{x}$ ); D--->y; (level tune); - (place of omission of units); S (syllable) and W (word)².

This study focuses on statement, question, request, command, telephone numbers, names, list to present the structure being proposed for tone-reading in SBE and regional Englishes such as Nigerian English. This study presents one acceptable and one unacceptable readings of grammatical units (in terms of their conformity or divergence from the suprasegmental features of Standard British English and its equivalents) 3. The presentation is done in this order: List, Statement, Question, Request, Command and Telephone Number:

List:

\section{Rowland, John, Terry and Paulina}

Acceptable:

$\begin{array}{llllllll}\text { Row- } & \text {-land } & \text { John } & \text { Terry } & \text { and } & \text { Pau- } & \text { li- } & \text { na } \\ \text { Din } & \text { Don } & \text { D--->n } & \text { D--->n } & \text { Din } & \text { Din }^{\text {Deg. } 1} & \text { Din }^{\text {Deg. } 2} & \text { Don }\end{array}$

Unacceptable:

$\begin{array}{llllllll}\text { Row- } & \text { land } & \text { John } & \text { Terry } & \text { and } & \text { Pau- } & \text { li- } & \text { na } \\ \text { Doy } & \text { Din } & \text { D--->y } & \text { D--->y } & \text { Din } & \text { Din }^{\text {Deg. 2 }} & \text { Din }^{\text {Deg.3 }} & \text { Don }\end{array}$

Statement:

I have promoted him. 
Proposing a Pitch-meter for English Tone-reading

\begin{tabular}{|c|c|c|c|c|}
\hline I & have & pro- & mo- & -ted \\
\hline Din & Don & D---> & Din & Don \\
\hline
\end{tabular}

Unacceptable:

I have pro- mo- ted him.

Din Din Doy Din Don Din

Question:

Where have you been?

Acceptable:

Where have you been ${ }^{4}$ ?

Don Din Din ${ }^{\text {Deg. } 2} \quad$ Din ${ }^{\text {Deg. } 3}$

Unacceptable:

Where have you been?

Din Doy Din Din ${ }^{\text {Deg. } 2}$

Request:

Can you please lend me your pen?

Acceptable:

Don Din

please

lend

me

your

pen $^{5}$ ?

Unacceptable:

Can you

Din ${ }^{\text {Deg.2 }}$

Din ${ }^{\text {Deg.3 }}$

D--->n

D--->n

Din Deg.4

please lend

Din Deg.3

me

your

pen?

Din

Doy

Din Deg.2

D--->y

D--->y

Din ${ }^{\text {Deg.4 }}$

Command:

Open that door.

Acceptable:

O- pen

Din Don

that

door.

Unacceptable:

D--->y

D--->n

O- pen

that door.

Din Din

D--->y

Don

Telephone Numbers:

Zero three four, six seven, nine three two eight, four nine 


\section{Acceptable:}

Zero three four, six seven, nine three two eight, four nine

Din Din ${ }^{\text {Deg. } 2}$ Don $\quad$ Din Don $\quad$ Din Din $^{\text {Deg. } 2}$ Din ${ }^{\text {Deg. } 3}$ Din ${ }^{\text {Deg. } 4}$ Don Don $^{\text {Deg. } 2}$

Unacceptable:

Zero three four, six seven, nine three two eight, four nine

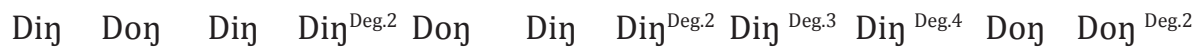

\section{Discussion AND CONCLUSION}

Phonology is the study of the 'functions' and 'patterning systems' of sounds in language. Human beings have the ability to produce and perceive a wide range of speech sounds, yet there is no natural language that explores all such available phonetic data. Rather, languages scrutinize and select such speech sounds and organize them to form a regular linguistic system. Grammatical constraints which inform the selection, arrangement and variation of speech sounds in language are known as phonology. The phonetic system that constitutes the phonological system is covertly resident in speakers. It is therefore not surprising that speakers of English know acceptable and non-acceptable combinations of consonants in words.

The way words and stretches are read or uttered is sometimes determined by regional factors. For example, Acheoah (ibid.) posits that Standard Nigerian English which remains a front-burner sociolinguistic discourse differs slightly from Standard British English as far phonology is concerned. The three major languages in Nigeria impinge on the suprasegmental corpora of Nigerian English. There are critical submissions on the suprasegmental features of Nigerian English; see Akindele and Adegbite (1999), Kujore (1985) and Jowitt (1991) for insights on this. They hold the view that in NE, high tones do not necessarily correlate with stressed syllables. There is the common claim that Nigerian English is syllable-timed. The practice of stressing virtually all syllables in words is typical of Nigerian English. Scholars opine that a major cause of this is that many Nigerian languages have only the tonic syllable. Udofot (2000) cited in Acheoah (ibid.) compares Nigerian English rhythm to the pulsation of African drum which she observes is rhythmic and not varying in tempo. She holds the view that the degree at which Nigerian speakers' stress pattern deviates from Standard English reduces as they move up the ladder to the sophisticated Nigerian English variety (SNE). She proposes the use of full-vowel timing as an alternative description of NE rhythm. Akinjobi (2002:45) views intonation as a major feature of many languages. He asserts that in tonal languages such as Nigerian languages, variation in pitch is used to contrast the meaning of individual words while in intonational languages such as English it is the feature of the word group. In this study, my aim is to present acceptable suprasegmental productions that may not necessarily strictly conform to the ways native speakers of English read words and stretches. Therefore, I contend that the pitch meter presented in this study aligns with Standard Nigerian English (SNE).

Hinging on the Notational Model, this study examines how pitch types in English are read. Falling pitches in statements depict end of the sentence (terminal intonation contour). Lists, questions and telephone numbers are called non-terminal intonation contours, to which a level-tune also belongs. Speakers of English, like speakers of any other language, can control pitch levels when they speak. This process presupposes controlling the pressure of air that "invades" the vocal cords as well as the quantity of air that passes through the glottis. Two types of 
controlled pitch movements in human languages are: "tone" and "intonation". The falling tune noticeable at the end of a statement indicates sentential completeness (terminal intonation contour). Conversely, the rising or level intonation or pitch at the non-final forms in lists and telephone numbers is known as "non-terminal intonation contour"; it indicates incompleteness.

Rising intonation on names and requests is commonly heard in addressing people; it shows that the speaker is opening a conversation or some further action is expected from the addressee. Rising intonation is often used to express politeness. All sounds have in-built suprasegmental properties (pitch, loudness and length) irrespective of their place and manner of articulation. All phones (sounds) give subjective impression of being relatively higher or lower in pitch (the measurable auditory property of sounds). Pitch contours in the corpora treated in this study are influenced by different phonological constraints. For example, pitch is salient in sonorous sounds such as vowels, liquids, glides and nasal sounds. It is worthy of note that even fricatives do not convey same pitch levels when their articulation is sustained for a longer time as a speaker switches from the production of $/ \mathrm{s} /$ to $/ \mathrm{J} /$.

\section{NOTES}

1. Acheoah (ibid.) attempted the structure of pitch-meter in contrasting British English and Nigerian English.

This new model (Notational Model) is not restricted to tone-reading in English alone. It reads words and stretches in any language.

2. When English is spoken, both the rising and falling tunes do not have stable pitch level. There are usually intonation contours (pitch boundaries); therefore, "Deg.x" accounts for speakers' moves from a particular low pitch level to a higher one, no matter how little the additional pitch level. As the fluctuating pitch contours of Din increases, superscript ${ }^{\mathrm{x}}$ increases in Hindu Arabic Numerals. On the other hand, ${ }^{\mathrm{x}}$ decreases in Hindu Arabic numerals as Doy decreases.

This study uses Din as Din Deg.1 hence the subscript "1" is implied. Similarly, Doy implies Don Deg.1.There cannot be "Deg.2" for either the falling tune I or the rising tune II without an immediate preceding higher tune I or lower to capture the shift in pitch (pitch contours).

The omitted unit represented by the hyphen (-) may be a syllable or a morpheme (grammatically meaningful linguistic item). But in this proposal, it is not necessarily so. It is more convenient to view the omitted units as phonemes.

This researcher hinges on two morphological units ("the Word" and "the Syllable") to explain three facts: pitch movement is not restricted to connected speech; syllables influence sound quality of words because they carry stress; the sound quality of any stretch of utterance is determined by stress placement on its constituent syllables and words. The level pitch is important in indicating points at which no pitch contour is produced. There are cases where a particular pitch contour is reproduced before and after in succession. The falling and rising tunes are level tunes when reproduced before and after in at least two successions.

3. There are other acceptable and unacceptable productions of each of component. I present just a single example for each since this paper is merely a proposal on pitch-meter for tone- reading in English.

4. English sentences that contain "wh-" words used for questioning (e.g. what, where, whose, who, why) do not have rising intonation. These question words themselves have in-built potentials to indicate that a response (answer) is expected from the hearer. 
Proposing a Pitch-meter for English Tone-reading

5. The level tune retains the pitch contour/level of its antecedent (linguistic unit that initiates it). Therefore, the next rise in pitch contour is marked sequentially as that of this initiator.

The modal auxiliaries "can", "will", "may" "could", etc. used for questioning have same potentials as "wh-" in which case they do not take rising intonation.

\section{REFERENCES}

Acheoah, J. E. (2013). “Phonology of Nigerian English.” In: Ayodabo J. O. and Butari P. N.

Issues in Language and Linguistics: The Nigerian Perspective. Kaduna: Language Study Group: 1-12.

Akindele, F. and Adegbite, Wale. (1999). The Sociology and Politics of English in Nigeria: An Introduction. Ile-Ife: Obafemi Awolowo University Press.

Akinjobi, A. (2002). "Nigerian English or Standard English Supra-segmentals: The question of what variety to teach." In Babatunde, S. and Adeyanju, D. Language, Meaning and Society. Ilorin: Haytee Press, 2002:30-50.

Awonusi, Victor O. (2004). Some Characteristics of Nigerian English Phonology. In Kofi Datzie and Segun Awonusi (eds.) Nigerian English: Influences and Characteristics (pp. 203-25). Lagos: Concept Publications.

Czaykowska-Hogins, Ewa and Dobrovolsky, Michael. (2004). "Phonology: The Function and Patterning of Sounds." In O'Grady, W. and Archibald, J. (eds.) Contemporary Linguistic Analysis: An Introduction.Canada: Pearson Education Canada Inc.

Gimson, A. C. (1970) An Introduction to the Pronunciation of English. London: Edward Arnold/New York: St. Martins Press.

Jowitt, D. (1991). Nigerian English Usage: An Introduction. London: Longman.

Kujore, O. (1985). English Usage: Some Notable Nigerian Variations. Ibadan: Evans Brothers.

Ladefoged, P. (1975). A Course in Phonetics. New York: Harcourt Bruce Jovanovich, Inc.

Roach, Peter. (2000). English Phonetics and Phonology: A Practical Course. 3rd ed. Cambridge: Cambridge University Press.

Roach, Peter, James Hartman, Jane Setter, \& David Jones (2006). The Cambridge English Pronunciation Dictionary (7th ed.). Cambridge University Press.

Citation: Acheoah, John Emike (PhD), "Proposing a Pitch-meter for English Tone-reading ". American Research Journal of English and Literature; V3, I1; pp:1-6.

Copyright (c) 2017 Acheoah, John Emike (PhD), This is an open access article distributed under the Creative Commons Attribution License, which permits unrestricted use, distribution, and reproduction in any medium, provided the original work is properly cited. 